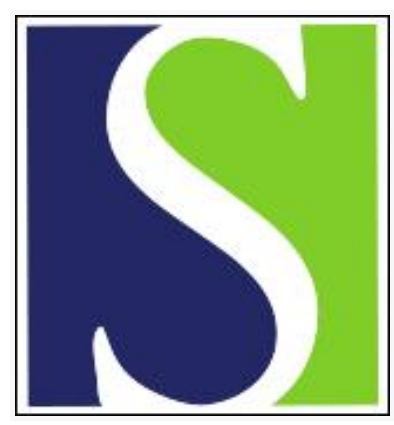

Scand J Work Environ Health 1993;19(6):375-381

https://doi.org/10.5271/sjweh.1459

Issue date: 01 Dec 1993

Chromosome aberrations in chloralkali workers previously exposed to mercury vapor.

by Hansteen IL, Ellingsen DG, Clausen KO, Kjuus H

Affiliation: Department of Occupational Medicine, Telemark Central Hospital, Skien, Norway.

This article in PubMed: www.ncbi.nlm.nih.gov/pubmed/8153588

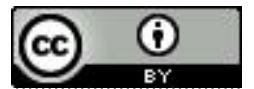




\title{
Chromosome aberrations in chloralkali workers previously exposed to mercury vapor
}

\author{
by Inger-Lise Hansteen, MSc, Dag G Ellingsen, MD, Kjell O Clausen, Helge Kjuus, MD'
}

\begin{abstract}
HANSTEEN I-L, ELLINGSEN DG, CLAUSEN KO, KJUUS H. Chromosome aberrations in chloralkali workers previously exposed to mercury vapor. Scand J Work Environ Health 1993;19:375-81. Chromosome aberrations and micronuclei in peripheral lymphocytes were studied in 29 male chloralkali workers previously exposed to mercury vapor and in two matched reference groups comprising 29 nitrate fertilizer workers and 29 customs and police officers. The study was performed using wholeblood cultures with and without hydroxyurea and caffeine to inhibit deoxyribonucleic acid synthesis and repair, respectively. No significant differences in the frequencies of chromosome aberrations and micronuclei were observed. However, a nonsignificant increase in chromosome breaks and dicentrics was found in the subgroups with high urinary mercury peak levels or high cumulative mercury exposure. An increased prevalence of "high" scores of chromatid breaks in the inhibited cultures, exceeding the 75th percentile of all of the subjects studied, was observed for the chloralkali workers when compared with both reference groups. No evident cytogenetic effects were observed among the chloralkali workers with the methods used in the present study.
\end{abstract}

Key terms: chromosome aberrations, genotoxic effects, inorganic mercury, micronuclei.

Inhaled mercury vapor is oxidized to bivalent mercury in the blood. However, prior to oxidation, elemental mercury can penetrate into different tissues through biological membranes (1) and persist for many years after the cessation of exposure (2).

It has been reported that inorganic mercury inactivates the mitotic spindle in dividing cells, ancuploidy or polyploidy being the most evident genotoxic effect (3). In human studies, micronucleus assay indicated an accumulation of cytogenetic damage in lymphocytes after exposure to mercury vapor (4) or mercury fulminate (5). Previous studies on humans during ongoing exposure to inorganic mercury compounds showed conflicting results when other cytogenetic methods were used (6-9).

Exposure to mercury vapor may constitute a health hazard to chloralkali workers. The aim of the present investigation was to study potential genotoxic effects of mercury vapor exposure among chloralkali workers after the cessation of exposure. The chromosome aberration method, with and without compounds inhibiting deoxyribonucleic acid (DNA) synthesis and repair, and the micronucleus assay were applied.

\section{Subjects and methods}

\section{Subjects}

The present study was part of a comprehensive study on possible adverse health effects in 77 male chlor-

\footnotetext{
1 Department of Occupational Medicine, Telemark Central Hospital, Skien, Norway.
}

Reprint requests to: Dr I-L Hansteen, Department of Occupational Medicine, Telemark Central Hospital, N-3710 Skien, Norway. alkali workers previously exposed to mercury vapor. A group of 53 male workers from a nitrate fertilizer plant served as the referents. Details of the main study design have been presented elsewhere (10). Among these 77 workers, 30 highly exposed subjects were selected, on the basis of a long duration or high level of exposure. They were individually matched with 30 referents among the 53 nitrate fertilizer workers (reference group I). The matching criteria were current smoking status (smoker/nonsmoker) and age ( \pm 5 years). Attempts were also made to match the current consumption of tobacco as closely as possible in the matched pairs. The referents in group I were employed in the same industrial complex where the chloralkali plant was situated. An external reference group (reference group II), comprising male customs and police officers, was also established according to the same matching criteria. One subject in reference group I withdrew from the study. Therefore each of the three groups comprised 29 subjects.

Some characteristics of the subjects under study are presented in tables 1 and 2 . The prevalence of infections, vaccinations, and $\mathrm{X}$-ray examinations and the use of drugs during the previous two years were comparable in the groups and were thus not considered further. Two subjects in reference group II who were initially identified as nonsmokers were found to be smokers when the questionnaires were reevaluated after the statistical comparisons were performed (See the Discussion.)

The current concentrations of mercury in whole blood and urine, and selenium in whole blood and urine were determined for the exposed subjects and reference group I with atomic absorption spectrometry (11). The accuracy and precision of the measurements in whole blood were monitored by the use 
Table 1. Some characteristics of the subjects under study.

\begin{tabular}{|c|c|c|c|c|c|c|c|c|c|c|c|c|c|c|c|c|c|c|}
\hline \multirow[t]{2}{*}{ Group } & \multicolumn{3}{|c|}{$\underset{(\mathrm{N})}{\text { Smoking status }}$} & \multicolumn{3}{|c|}{ Age (years) } & \multicolumn{3}{|c|}{$\begin{array}{l}\text { Current use of } \\
\text { tobacco }\left(g \cdot \text { week }^{-1}\right)\end{array}$} & \multicolumn{3}{|c|}{$\begin{array}{c}\text { Life-time } \\
\text { consumption } \\
\text { of tobacco }(\mathrm{kg})\end{array}$} & \multicolumn{3}{|c|}{$\begin{array}{c}\text { Current use of } \\
\text { coffee } \\
\text { (cups } \cdot d^{-1} \text { ) }\end{array}$} & \multicolumn{3}{|c|}{$\begin{array}{c}\text { Current alcohol use } \\
\left(1 \cdot \text { month }^{-1)}\right.\end{array}$} \\
\hline & $\begin{array}{l}\text { Pres- } \\
\text { ent }\end{array}$ & Past & Never & Mean & $\begin{array}{l}\text { Me- } \\
\text { dian }\end{array}$ & Range & Mean & $\begin{array}{l}\text { Me- } \\
\text { dian }\end{array}$ & Range & Mean & $\begin{array}{l}\text { Me- } \\
\text { dian }\end{array}$ & Range & Mean & $\begin{array}{l}\text { Me: } \\
\text { dian }\end{array}$ & Range & Mean & $\begin{array}{l}\text { Me- } \\
\text { dian }\end{array}$ & Range \\
\hline $\begin{array}{l}\text { Exposed } \\
(N=29)\end{array}$ & 15 & 9 & 5 & 48 & 48 & $31-65$ & 40.3 & 10 & $0-150$ & 76.7 & 62 & $0-335$ & 5.5 & 5 & $0-12$ & 0.4 & 0.2 & $0-2.0$ \\
\hline $\begin{array}{l}\text { Reference } 1 \\
(N=29)\end{array}$ & 15 & 13 & 1 & 48 & 50 & $32-64$ & 41.9 & 40 & $0-150$ & 75.6 & 60 & $0-218$ & 6.8 & 6 & $3-15$ & 0.2 & 0.2 & $0-0.7$ \\
\hline $\begin{array}{l}\text { eference II } \\
v=29 \text { ) }\end{array}$ & 17 & 2 & 10 & 48 & 50 & $30-66$ & 48.8 & 35 & $0-140$ & 77.1 & 67.5 & $0-280$ & 4.5 & 4 & $1-12$ & 0.2 & 0.1 & $0-0.8$ \\
\hline
\end{tabular}

Table 2. Mercury and selenium concentrations in the blood and urine of the subjects at the time of the study. (ND = not determined)

\begin{tabular}{|c|c|c|c|c|c|c|c|c|c|c|c|c|}
\hline \multirow{3}{*}{ Group } & \multicolumn{6}{|c|}{ Concentration in blood } & \multicolumn{6}{|c|}{ Concentration in urine } \\
\hline & \multicolumn{3}{|c|}{$\begin{array}{c}\text { Mercury } \\
\left(\mathrm{nmol} \cdot \mathrm{I}^{-1}\right)\end{array}$} & \multicolumn{3}{|c|}{$\begin{array}{l}\text { Selenium } \\
\left(\left.\mu \mathrm{mol} \cdot\right|^{-1}\right)\end{array}$} & \multicolumn{3}{|c|}{$\begin{array}{c}\text { Mercury } \\
\text { (nmol } \cdot \text { mmol } \\
\text { creatinine }{ }^{-1} \text { ) }\end{array}$} & \multicolumn{3}{|c|}{$\begin{array}{l}\text { Selenium } \\
\text { (nmol } \cdot \mathrm{mmol}^{-} \\
\text {creatinine }{ }^{-1} \text { ) }\end{array}$} \\
\hline & Mean & Median & Range & Mean & Median & Range & Mean & Median & Range & Mean & ledian & Range \\
\hline $\begin{array}{l}\text { Exposed } \\
(N=29)\end{array}$ & 28.8 & 28 & $12-61$ & 1.6 & 1.6 & $1.2-2.0$ & 2.2 & 1.7 & $0.5-6.1$ & 30.4 & 29 & $7-63$ \\
\hline $\begin{array}{l}\text { Reference I } \\
(N=29)\end{array}$ & 27.9 & 26 & $17-50$ & 1.6 & 1.6 & $1.4-2.0$ & 1.2 & 1.1 & $0.3-2.5$ & 39.9 & 39 & $25-56$ \\
\hline $\begin{array}{l}\text { Reference II } \\
(N=29)\end{array}$ & ND & & & ND & & & ND & & & ND & & \\
\hline
\end{tabular}

of Seronorm $^{(1)}$ trace-element whole-blood quality assurance materials, batch 904,905 and 906 . The detection limit of the method was $3 \mathrm{nmol} \cdot \mathrm{l}^{\prime}$ for mercury and $0.02 \mu \mathrm{mol} \cdot \mathrm{I}^{\mathrm{t}}$ for selenium. Human-quality assurance urine, Seronorm ${ }^{(8)}$ trace element, batch 108 , was used for the quality control of the urine analyses. The detection limit was $2 \mathrm{nmol} \cdot 1$ ' for mercury and $0.0005 \mu \mathrm{mol} \cdot \mathrm{l}^{-1}$ for selenium. Selenium was determined because it is known to interact with inorganic mercury in the body $(1-2)$. The current concentrations were low for both the exposed subjects and reference group I.

\section{Exposure assessment}

The chloralkali plant under study started production in 1947 and was closed at the end of 1987. The study was carried out in 1989. Biological monitoring of the employees through the determination of urinary mercury began in 1948. Results from 1434 urinary mercury measurements performed during the time of exposure were identified for the 29 exposed subjects. On the basis of these results, an individual cumulative "dose" estimate of urinary mercury was calculated as the sum of all individual mean annual urinary mercury concentrations. Further details regarding the biological monitoring of the workers and the calculation of cumulative urinary mercury have been given elsewhere (10).

The chloralkali workers had, on the average, been exposed to mercury vapor for 11.8 (median 10.3, range $1.7-36.2$ ) years. Their mean annual urinary mercury concentration was 611 (median 514, range 231-2921) $\mathrm{nmol} \cdot \mathrm{1}^{-1}$, and the mean cumulative urinary mercury concentration was 5827 (median 4843, range 1979-17 229) $\mathrm{nmol} \cdot 1{ }^{1}$. Exposure had started on the average 22.9 (median 21.0, range 8.0-41.0) years prior to the study and ceased on an average of 9.9 (median 2.0, range 1.0-33.0) years prior to the study. Seventeen subjects had urinary mercury concentrations that exceeded $1500 \mathrm{nmol} \cdot \mathrm{l}^{\prime}$, and for nine subjects the urinary mercury concentration exceeded $3000 \mathrm{nmol} \cdot \mathrm{l}^{\text {' }}$ at least once during their period of exposure. Table 3 presents the distribution of the cumulative urinary mercury concentrations and the annual mean urinary mercury concentration in relation to the number of years exposed.

\section{Cytogenetic examinations}

All of the blood samples were collected and processed on the same day for the matched triplets. For the scoring of chromosome aberrations, whole blood was cultured for $48-53 \mathrm{~h}$ in $\mathrm{HamF} 10^{(\mathrm{kis})}$ with Lglutamin, supplemented with $20 \%$ fetal calf serum, $3 \%$ penicillin $\left(5000 \mathrm{IU} \cdot \mathrm{ml}^{1}\right) /$ streptomycin $(5000$ $\mu \mathrm{g} \cdot \mathrm{ml}^{-1}$ ) (all from Flow Laboratories, Biggio, Switzerland), and $0.8 \%$ phytohemagglutinin P-form (Difco, Michigan, United States). For the conventional cultures, $0.3 \mu \mathrm{g} \cdot \mathrm{ml}^{1}{ }^{1}$ Demekolcin ${ }^{(i)}$ (Rikshospitalet, Oslo, Norway) was added $3 \mathrm{~h}$ before the harvesting. Inhibition of the DNA synthesis and repair was ac- 
complished in parallel cultures with hydroxyurea (Sigma, St Louis, United States) and caffeine (Sigma) both at a $7.5 \cdot 10^{-3} \mathrm{M}$ concentration, added together with Demekolcin ${ }^{\circledR} 3 \mathrm{~h}$ prior to the harvesting, as described previously (12). The preparations were stained with Giemsa (Merck, Darmstadt, Germany), and 100 mitoses for the conventional analysis and 50 mitoses for cultures for DNA synthesis and repair inhibition were scored for aberrations such as chromatid and chromosome breaks, exchanges, dicentrics, rings, acentric fragments, marker chromosomes, gaps, and aneuploid cells. The aneuploid cells included both hypo- and hyperdiploid cells. Aneuploidy and gaps were not included in the cells with aberrations. All of the counts have been given per 100 cells, except for dicentrics, for which the total number for each group has been given.

For the micronucleus assay, whole blood was cultured for $72 \mathrm{~h}$ in the same medium as described previously, the last $24 \mathrm{~h}$ with Cytochalasin $\mathrm{B}^{\circledR}$ (Sigma) in a concentration of $3 \mu \mathrm{l} \cdot \mathrm{ml}^{-1}(13)$. The cells were harvested and stained with Acridine Orange ${ }^{(M)}$ (Merck) (14). For each subject 1000 binucleated cells were scored.

The scoring was equally divided between three experienced scorers without knowledge of the exposure status. One matched triplet was always scored by the same person.

\section{Statistical methods}

The cytogenetic results of the exposed group were compared with the results of the two reference groups separately with the use of the nonparametric Wilcoxon's matched-pair signed rank test.

Spearman's rank correlation was calculated to study the univariate relationships between the cytogenetic variables and the exposure and life-style parameters. The level of significance was set at 5\% (twotailed).

Cytogenetic scores exceeding the 75th percentile among all of the subjects under study were regarded as "high." This cut point was chosen a priori to secure an appropriate size for the study groups. If the 75th percentile included more than one value, the next unique cut point lower than the 75th percentile was chosen. Mantel-Haenszel's test for odds ratio (OR) with the $95 \%$ confidence interval was applied in order to study the distribution of "high" cytogenetic scores among the participants.

The statistical analyses were carried out on a personal computer using BMDP statistical software, PC 90 version (BMDP Statistical Software, Inc, Los Angeles, California).

\section{Results}

The results of the cytogenetic examinations made with conventional methods are presented in table 4. No significant differences were observed for any of
Table 3. Distribution of the cumulative level of urinary mercury and the annual individual mean urinary mercury concentration of 29 chloralkali workers in relation to the time exposed.

\begin{tabular}{|c|c|c|c|c|c|c|}
\hline & \multicolumn{6}{|c|}{ Period exposed } \\
\hline & \multicolumn{2}{|c|}{$1-9$ years } & \multicolumn{2}{|c|}{$\begin{array}{c}10-14 \\
\text { years }\end{array}$} & \multicolumn{2}{|c|}{$\geq 15$ years } \\
\hline & $\mathrm{N}$ & $\%$ & $\mathrm{~N}$ & $\%$ & $\mathrm{~N}$ & $\%$ \\
\hline \multicolumn{7}{|c|}{$\begin{array}{l}\text { Cumulative level of } \\
\text { urinary mercury } \\
\left.\text { (nmol }\left.\cdot\right|^{-1}\right)\end{array}$} \\
\hline $\begin{array}{r}0-2999 \\
3000-5999 \\
\geq 6000\end{array}$ & $\begin{array}{l}6 \\
7 \\
1\end{array}$ & $\begin{array}{r}20.7 \\
24.1 \\
3.4\end{array}$ & $\begin{array}{l}2 \\
2 \\
3\end{array}$ & $\begin{array}{r}6.9 \\
6.9 \\
10.3\end{array}$ & $\begin{array}{l}0 \\
2 \\
6\end{array}$ & $\begin{array}{c}0 \\
6.9 \\
20.7\end{array}$ \\
\hline \multicolumn{7}{|c|}{$\begin{array}{l}\text { Mean annual level of } \\
\text { urinary mercury } \\
\left.\text { (nmol }\left.\cdot\right|^{-1}\right)\end{array}$} \\
\hline $\begin{array}{r}0-399 \\
400-599 \\
\geq 600\end{array}$ & $\begin{array}{l}3 \\
6 \\
5\end{array}$ & $\begin{array}{l}10.3 \\
20.7 \\
17.2\end{array}$ & $\begin{array}{l}4 \\
2 \\
1\end{array}$ & $\begin{array}{r}13.8 \\
6.9 \\
3.4\end{array}$ & $\begin{array}{l}3 \\
4 \\
1\end{array}$ & $\begin{array}{r}10.3 \\
13.8 \\
3.4\end{array}$ \\
\hline
\end{tabular}

the cytogenetic parameters when all of the exposed subjects or all of the subjects for whom the exposure had ceased within the last two years were compared with the results of the two separate reference groups. A statistically nonsignificant difference $(\mathrm{P}=$ 0.06) was observed for chromosome breaks and cells with micronuclei among the workers with a cumulative urinary mercury concentration of $\geq 5000$ nmol $\cdot l^{-1}$ when they were compared with reference group II. The subjects with a urinary mercury peak level of $\geq 1500 \mathrm{nmol} \cdot \mathrm{l}^{-1}$ also had a nonsignificantly higher number of chromosome breaks, and more cells with micronuclei than subjects in reference group II $(\mathrm{P}=0.05)$. However, reference group I had an even higher number of cells with micronuclei than the exposed subjects with a urinary mercury peak of $\geq 1500 \mathrm{nmol} \cdot \mathrm{l}^{-1}$ or a cumulative urinary mercury value of $\geq 5000 \mathrm{nmol} \cdot 1^{-1}$. The number of exposed subjects with dicentric chromosomes was small, but higher than in either reference group. A maximum of one dicentric chromosome was observed per person. No significant intergroup differences were observed for chromatid and chromosome gaps, chromatid exchanges, rings, markers, and minutes (results not presented).

The mean values for all of the cytogenetic parameters were increased in cultures used for the DNA synthesis and repair inhibition when they were compared with the results of the conventional cultures, but no significant intergroup differences were observed between the exposed subjects or selected subgroups of the exposed subjects and the matched referents (table 5). However, the prevalence of "high" scores of chromatid breaks in the inhibited cultures was significantly higher among the exposed subjects than among either of the reference groups (table 6).

In the inhibited cultures the percentage of chromatid breaks among the exposed subjects and reference group I was 12.5 versus 8.7 for the smokers and 6.6 versus 4.6 for the nonsmokers, respectively. The 
Table 4. Results of the cytogenetic examination with conventional cell cultures for all of the exposed subjects and selected subgroups compared with the two reference groups (aberrations per $100 \mathrm{cells}$, micronuclei per 1000 cells).

\begin{tabular}{|c|c|c|c|c|c|c|c|c|c|c|c|c|}
\hline \multirow{2}{*}{$\begin{array}{l}\text { Group or } \\
\text { subgroup }\end{array}$} & \multirow{2}{*}{$\begin{array}{l}\text { Number } \\
\text { of } \\
\text { subjects }\end{array}$} & \multicolumn{2}{|c|}{$\begin{array}{l}\text { Chromatid } \\
\text { breaks }\end{array}$} & \multicolumn{2}{|c|}{$\begin{array}{c}\text { Chromosome } \\
\text { breaks }\end{array}$} & \multicolumn{2}{|c|}{$\begin{array}{l}\text { Cells with } \\
\text { aberrations }\end{array}$} & \multirow{2}{*}{$\begin{array}{l}\text { Dicen- } \\
\text { trics } \\
\left(\mathrm{N}^{\mathrm{a}}\right)\end{array}$} & \multicolumn{2}{|c|}{$\begin{array}{l}\text { Aneuploid } \\
\text { cells }\end{array}$} & \multicolumn{2}{|c|}{$\begin{array}{l}\text { Cells with } \\
\text { micronuclei }\end{array}$} \\
\hline & & Mean & Range & Mean & Range & Mean & Range & & Mean & Range & Mean & Ranye \\
\hline \multicolumn{13}{|l|}{ All subjects } \\
\hline $\begin{array}{l}\text { Exposed group } \\
\text { Reference group I } \\
\text { Reference group II }\end{array}$ & $\begin{array}{l}29 \\
29 \\
29\end{array}$ & $\begin{array}{l}0.66 \\
0.31 \\
0.69\end{array}$ & $\begin{array}{l}0-4 \\
0-2^{*} \\
0-4\end{array}$ & $\begin{array}{l}0.59 \\
0.52 \\
0.35\end{array}$ & $\begin{array}{l}0-4 \\
0-3 \\
0-2\end{array}$ & $\begin{array}{l}1.41 \\
1.21 \\
1.38\end{array}$ & $\begin{array}{l}0-7 \\
0-4 \\
0-4\end{array}$ & $\begin{array}{l}4 \\
2 \\
2\end{array}$ & $\begin{array}{l}2.45 \\
3.28 \\
2.72\end{array}$ & $\begin{array}{l}0-8 \\
0-10 \\
0-7\end{array}$ & $\begin{array}{l}6.62 \\
6.31 \\
5.41\end{array}$ & $\begin{array}{l}2-28 \\
2-17 \\
0-17\end{array}$ \\
\hline \multicolumn{13}{|l|}{$\begin{array}{l}\text { Exposure cessation } \\
\leq 2 \text { years prior } \\
\text { to the study }\end{array}$} \\
\hline $\begin{array}{l}\text { Exposed group } \\
\text { Reference group I } \\
\text { Reference group II }\end{array}$ & $\begin{array}{l}14 \\
14 \\
14\end{array}$ & $\begin{array}{l}0.43 \\
0.29 \\
0.57\end{array}$ & $\begin{array}{l}0-2 \\
0-1 \\
0-3\end{array}$ & $\begin{array}{l}0.43 \\
0.64 \\
0.36\end{array}$ & $\begin{array}{l}0-2 \\
0-3 \\
0-2\end{array}$ & $\begin{array}{l}1.00 \\
1.21 \\
1.21\end{array}$ & $\begin{array}{l}0-2 \\
0-4 \\
0-4\end{array}$ & $\begin{array}{l}2 \\
1 \\
1\end{array}$ & $\begin{array}{l}2.00 \\
3.00 \\
2.71\end{array}$ & $\begin{array}{l}0-6 \\
0-10 \\
0-7\end{array}$ & $\begin{array}{l}8.07 \\
5.79 \\
6.15\end{array}$ & $\begin{array}{l}3-28 \\
2-17 \\
1-17\end{array}$ \\
\hline \multicolumn{13}{|l|}{$\begin{array}{l}\text { Peak level of } \\
\text { urinary mercury } \\
\geq\left. 1500 \mathrm{nmol} \cdot\right|^{-1} \\
\text { at least once }\end{array}$} \\
\hline $\begin{array}{l}\text { Exposed group } \\
\text { Reference group I } \\
\text { Reference group II }\end{array}$ & $\begin{array}{l}17 \\
17 \\
17\end{array}$ & $\begin{array}{l}0.59 \\
0.23 \\
0.94\end{array}$ & $\begin{array}{l}0-4 \\
0-1 \\
0-4\end{array}$ & $\begin{array}{l}0.94 \\
0.52 \\
0.29\end{array}$ & $\begin{array}{l}0-4 \\
0-3 \\
0-2^{4}\end{array}$ & $\begin{array}{l}1.71 \\
1.24 \\
1.76\end{array}$ & $\begin{array}{l}0-7 \\
0-3 \\
0-4\end{array}$ & $\begin{array}{l}3 \\
1 \\
2\end{array}$ & $\begin{array}{l}2.88 \\
3.59 \\
3.06\end{array}$ & $\begin{array}{l}0-8 \\
0-10 \\
0-7\end{array}$ & $\begin{array}{l}5.88 \\
6.82 \\
4.89\end{array}$ & $\begin{array}{l}3-16 \\
2-15 \\
0-17^{\star \star}\end{array}$ \\
\hline \multicolumn{13}{|l|}{$\begin{array}{l}\text { Cumulative level } \\
\text { of urinary mercury } \\
\geq 5000 \mathrm{nmol} \cdot 1^{-1}\end{array}$} \\
\hline $\begin{array}{l}\text { Exposed group } \\
\text { Reference group } \mid \\
\text { Reference group if }\end{array}$ & $\begin{array}{l}13 \\
13 \\
13\end{array}$ & $\begin{array}{l}0.69 \\
0.15 \\
1.08\end{array}$ & $\begin{array}{l}0-4 \\
0-1 \\
0-4\end{array}$ & $\begin{array}{l}1.00 \\
0.54 \\
0.15\end{array}$ & $\begin{array}{l}0-4 \\
0-3 \\
0-1^{\star}\end{array}$ & $\begin{array}{l}2.00 \\
1.15 \\
1.77\end{array}$ & $\begin{array}{l}0-7 \\
0-3 \\
0-4\end{array}$ & $\begin{array}{l}3 \\
1 \\
1\end{array}$ & $\begin{array}{l}2.92 \\
3.84 \\
3.00\end{array}$ & $\begin{array}{l}0-8 \\
0-10 \\
0-7\end{array}$ & $\begin{array}{l}6.23 \\
7.23 \\
5.00\end{array}$ & $\begin{array}{l}3-16 \\
2-15 \\
0-17^{*}\end{array}$ \\
\hline
\end{tabular}

a $\mathrm{N}=$ Number of subjects.

${ }^{*} \mathrm{P}<0.10$, ${ }^{\star \star} \mathrm{P} \leq 0.05$ in comparison with the exposed.

Table 5. Results of the cytogenetic examination for deoxyribonucleic acid synthesis and repair inhibition in cultures from all of the exposed subjects and selected subgroups compared with the two reference groups (aberrations per 100 cells).

\begin{tabular}{|c|c|c|c|c|c|c|c|}
\hline \multirow{2}{*}{ Group or subgroup } & \multirow{2}{*}{ Number } & \multicolumn{2}{|c|}{ Chromatid breaks } & \multicolumn{2}{|c|}{$\begin{array}{l}\text { Chromosome } \\
\text { breaks }\end{array}$} & \multicolumn{2}{|c|}{$\begin{array}{l}\text { Cells with } \\
\text { aberrations }\end{array}$} \\
\hline & & Mean & Range & Mean & Range & Mean & Range \\
\hline \multicolumn{8}{|l|}{ All subjects } \\
\hline $\begin{array}{l}\text { Exposed group } \\
\text { Reference group I } \\
\text { Reference group II }\end{array}$ & $\begin{array}{l}29 \\
29 \\
29\end{array}$ & $\begin{array}{l}9.7 \\
6.7 \\
7.9\end{array}$ & $\begin{array}{l}0-36 \\
0-24 \\
0-22\end{array}$ & $\begin{array}{l}3.0 \\
2.4 \\
5.1\end{array}$ & $\begin{array}{l}0-30 \\
0-8 \\
0-32\end{array}$ & $\begin{array}{l}9.8 \\
8.5 \\
9.7\end{array}$ & $\begin{array}{l}0-24 \\
0-22 \\
0-26\end{array}$ \\
\hline \multicolumn{8}{|c|}{ Exposure cessation $\leq 2$ years } \\
\hline $\begin{array}{l}\text { Exposed group } \\
\text { Reference group I } \\
\text { Reference group II }\end{array}$ & $\begin{array}{l}14 \\
14 \\
14\end{array}$ & $\begin{array}{r}10.9 \\
7.7 \\
8.0\end{array}$ & $\begin{array}{l}0-36 \\
2-18 \\
2-22\end{array}$ & $\begin{array}{l}3.6 \\
2.4 \\
5.3\end{array}$ & $\begin{array}{l}0-30 \\
0-8 \\
0-32\end{array}$ & $\begin{array}{r}10.4 \\
9.7 \\
10.3\end{array}$ & $\begin{array}{l}2-18 \\
2-22 \\
4-18\end{array}$ \\
\hline \multicolumn{8}{|c|}{$\begin{array}{l}\text { Peak level of urinary mercury } \\
\geq 1500 \mathrm{nmol} \cdot 1^{-1}\end{array}$} \\
\hline $\begin{array}{l}\text { Exposed group } \\
\text { Reference group I } \\
\text { Reference group II }\end{array}$ & $\begin{array}{l}17 \\
17 \\
17\end{array}$ & $\begin{array}{l}8.7 \\
5.8 \\
7.1\end{array}$ & $\begin{array}{l}0-30 \\
0-24 \\
0-22\end{array}$ & $\begin{array}{l}1.7 \\
2.6 \\
3.1\end{array}$ & $\begin{array}{l}0-10 \\
0-6 \\
0-14\end{array}$ & $\begin{array}{l}9.1 \\
7.9 \\
8.2\end{array}$ & $\begin{array}{l}0-24 \\
0-22 \\
0-18\end{array}$ \\
\hline \multicolumn{8}{|c|}{$\begin{array}{l}\text { Cumulative level of urinary } \\
\text { mercury } \geq\left. 5000 \mathrm{nmol} \cdot\right|^{-1}\end{array}$} \\
\hline $\begin{array}{l}\text { Exposed group } \\
\text { Reference group I } \\
\text { Reference group II }\end{array}$ & $\begin{array}{l}13 \\
13 \\
13\end{array}$ & $\begin{array}{l}9.5 \\
7.1 \\
7.9\end{array}$ & $\begin{array}{l}0-30 \\
0-24 \\
0-22\end{array}$ & $\begin{array}{l}2.2 \\
2.3 \\
3.5\end{array}$ & $\begin{array}{l}0-10 \\
0-6 \\
0-14\end{array}$ & $\begin{array}{r}10.2 \\
8.9 \\
9.1\end{array}$ & $\begin{array}{l}0-24 \\
0-22 \\
0-18\end{array}$ \\
\hline
\end{tabular}

mean current blood mercury and blood selenium levels were comparable in these four subgroups, while the urinary mercury levels among the exposed smokers and nonsmokers was higher than among the referents (smokers: 2.3 versus $1.1 \mathrm{nmol} \cdot \mathrm{mmol}$ creatinine $^{-1}, \mathrm{P}=0.02$; nonsmokers: 2.2 versus $1.2 \mathrm{nmol}$. mmol creatinine ${ }^{-1}, \mathrm{P}=0.01$ ). The urinary selenium level was lower for the exposed smokers and nonsmokers than for their referents (smokers: 28.5 versus $39.8 \mathrm{nmol} \cdot \mathrm{mmol}$ creatinine ${ }^{-1}, \mathrm{P}=0.02$; nonsmokers: 32.5 versus $40.1 \mathrm{nmol} \cdot \mathrm{mmol}$ creatinine $^{-1}$, $\mathrm{P}=0.06$ ).

No statistically significant association was observed for any of the cytogenetic end points and the 
Table 6. Number of subjects with "high" scores (cut off 75th percentile) among the exposed subjects and reference groups I and II, with the odds ratios and $95 \%$ confidence intervals for the exposed group in comparison with the two reference groups separately.

\begin{tabular}{|c|c|c|c|c|c|c|c|}
\hline & \multirow[b]{2}{*}{$\begin{array}{l}\text { Exposed } \\
\text { group } \\
(\mathrm{N})\end{array}$} & \multicolumn{3}{|c|}{ Reference group I } & \multicolumn{3}{|c|}{ Reference group II } \\
\hline & & Number & $\begin{array}{l}\text { Odds } \\
\text { ratio }\end{array}$ & $\begin{array}{c}95 \% \\
\text { confidence } \\
\text { interval }\end{array}$ & Number & $\begin{array}{l}\text { Odds } \\
\text { ratio }\end{array}$ & $\begin{array}{c}95 \% \\
\text { confidence } \\
\text { interval }\end{array}$ \\
\hline \multicolumn{8}{|l|}{ Conventional cultures } \\
\hline $\begin{array}{l}\text { Chromatid breaks } \\
\text { Chromosome breaks } \\
\text { Cells with micronuclei }\end{array}$ & $\begin{array}{r}14 \\
11 \\
8\end{array}$ & $\begin{array}{r}8 \\
12 \\
10\end{array}$ & $\begin{array}{l}2.5 \\
0.9 \\
0.7\end{array}$ & $\begin{array}{l}0.8-7.3 \\
0.3-2.5 \\
0.2-2.2\end{array}$ & $\begin{array}{r}13 \\
7 \\
7\end{array}$ & $\begin{array}{l}1.2 \\
1.9 \\
1.1\end{array}$ & $\begin{array}{l}0.4-3.2 \\
0.6-6.0 \\
0.3-3.6\end{array}$ \\
\hline \multicolumn{8}{|l|}{ Inhibited cultures } \\
\hline $\begin{array}{l}\text { Chromatid breaks } \\
\text { Chromosome breaks }\end{array}$ & $\begin{array}{r}14 \\
9\end{array}$ & $\begin{array}{r}5 \\
11\end{array}$ & $\begin{array}{l}4.5^{*} \\
0.7^{2}\end{array}$ & $\begin{array}{l}1.3-15.0 \\
0.3-2.2\end{array}$ & $\begin{array}{r}6 \\
16\end{array}$ & $\begin{array}{l}3.6^{\star *} \\
0.4\end{array}$ & $\begin{array}{l}1.2-11.3 \\
0.1-1.1\end{array}$ \\
\hline
\end{tabular}

* $P=0.01,{ }^{* *} P=0.03$.

exposure-related parameters (cumulative urinary mercury concentration, current mercury concentration in the blood, urinary mercury concentration, and time since cessation of exposure) or life-style parameters (current tobacco and alcohol consumption, age). The exposed group and the two reference groups were studied separately. Furthermore, no significant correlations were found between any of the cytogenetic parameters scored in cultures with and without DNA synthesis and repair inhibition.

\section{Discussion}

With regard to the comparability of the selected groups in the present study, reference group I was potentially exposed to low levels of nitrate-containing dust but, to our knowledge, not to known clastogenic agents. The subjects in reference group II were not exposed to any chemical agents at work. The consistency of the results in the two reference groups varied, and a higher score was observed for subjects in one of the reference groups than in the exposed group for some of the studied parameters. However, the figures were small and subject to high random variability. The two excess smokers in reference group II could have led to an underestimation of a difference with the exposed group, but they had low scores for chromosome aberrations when compared with the nonsmokers in the same reference group.

No significant differences between the chloralkali workers previously exposed to mercury vapor and the referents were observed for any of the studied cytogenetic end points determined with conventional methods. For chromosome breaks and dicentrics, however, a nonsignificant increase was observed for the subgroups with the highest exposure in the present study (table 4). Other cytogenetic studies among workers no longer exposed to mercury vapor are not known to us.

Previous studies on the effects of ongoing exposure to inorganic mercury have shown conflicting results (4-9). Verschaeve et al (6) observed an increased prevalence of chromosome aberrations in 28 subjects exposed to various mercury compounds, but the results were not confirmed in a later study (7). Popescu et al (8) found an increase in chromosome aberrations, but no increase in chromatid-type aberrations in four subjects with repeatedly high urinary mercury concentrations reaching $890 \mu \mathrm{g} \cdot \mathrm{I}^{-1}$ (4450 $\left.\mathrm{nmol} \cdot \mathrm{1}^{-1}\right)$. At the time of the cytogenetic analysis the concentration varied between 100 and $420 \mu \mathrm{g} \cdot \mathrm{l}^{-1}$ (500 and $2100 \mathrm{nmol} \cdot \mathrm{l}^{-1}$ ). No smoking data were reported in that study. Mabille et al (9) did not observe any increased cytogenetic damage in 22 chloralkali workers. Barregård et al (4) observed an association between the number of micronuclei and cumulative mercury dose indicators. An increased prevalence of micronuclei was observed by Anwar \& Gabal (5) in workers exposed to mercury fulminate. If inorganic mercury acts as a spindle poison in man, as shown for eukaryotes (3), this might be one of the explanations for an increased prevalence of micronuclei. Although the prevalence of micronuclei in the present study was significantly higher among the exposed subjects with peak levels of urinary mercury exceeding $1500 \mathrm{nmol} \cdot \mathrm{l}^{-1}$ than among the matched referents in reference group II, the highest prevalence was observed for the subjects in reference group I. Furthermore, all of the exposed subjects had a higher prevalence of cells with micronuclei than the selected highly exposed subgroups. Therefore, the present results do not indicate any significant difference between the subgroups of exposed workers and the two independent reference groups for any of the studied cytogenetic end points either.

Increased cytogenetic damage, mainly of the chromatid type, was shown in the lymphocyte cultures for DNA synthesis and repair inhibition in studies with different types of in vitro mutagen treatment compared with conventional cultures $(15-17)$. In the inhibited cultures in the present study the prevalence of "high" scores of chromatid breaks (cut point: 75th percentile) was significantly higher among the exposed subjects than among either of the reference 
groups. When other cut points were used, the same, but nonsignificant trends were observed.

Chromatid breaks may reflect ongoing exposure to mutagens in addition to previous exposure. It was shown for patients with testicular cancer that chromatid breaks disappeared from the peripheral lymphocyte population faster than any of the other aberration types after the cessation of chemotherapy. Furthermore no increase above the reference level was detected after 19 months (18). The median for cessation of exposure in the present study was 24 months. As judged by the current blood mercury concentration, no occupational exposure to mercury vapor was occurring at the time of the blood sampling, while the difference in the current urinary mercury concentration between the exposed subjects and the referents may reflect previous exposure. Kosta et al (2) showed that substantial concentrations of mercury were present in former mercury miners many years after the cessation of mercury exposure. Tobacco smoke was probably the most important current exposure to mutagens for the subjects under study. An increased prevalence of chromatid breaks in inhibited cultures has been previously shown for smokers when they were compared with nonsmokers (12). In the present study the highest prevalence of chromatid breaks in the inhibited cultures was observed among previously exposed smokers, followed by smoking referents and exposed nonsmokers, while the nonsmoking referents had the lowest prevalence.

The exposed workers in the present study had lower current concentrations of urinary selenium than reference group I. Selenium has been shown to coaccumulate with inorganic mercury in several tissues in former mercury miners (2). Studies among chloralkali workers, both during ongoing $(19,20)$ and previous mercury vapor exposure (11), showed reduced concentrations of urinary selenium when they were compared with referents. The possible mechanism of interaction between selenium and inorganic mercury is not fully understood (1). However, selenium at nutritional levels is antimutagenic in different systems (21), and Morimoto et al (22) observed that selenite prevented the induction of sister chromatid exchanges by methyl mercury in human whole blood cultures. A high correlation between sister chromatid exchanges and chromatid breaks in inhibited cultures has been previously shown for smokers (12). Whether the interaction of inorganic mercury and selenium may lead to increased chromatid breaks from current exposure to mutagenic agents, such as smoking, is an interesting hypothesis which should be evaluated in further studies.

The mechanism of bivalent mercury toxicity at the cellular level is currently not well understood. Another possible mechanism of action could, however, be a lower level of DNA repair activity in tissues containing bivalent mercury. Robison et al (23) showed that the persistence of bivalent mercury in Chinese hamster ovary cells in culture can inhibit
DNA repair activity in cells at concentrations and exposure times for which DNA single-strand breaks, caused by bivalent mercury, could not be detected.

\section{Acknowledgments}

We thank Ms V Haugan, Ms H Schistad, and Ms G Flata for their technical assistance, Y Thomassen, MSc, for the mercury and selenium determinations in blood and urine, and Ms P Flor for her linguistic assistance.

The study was carried out with financial support from Norsk Hydro A/S, Norway.

\section{References}

1. Berlin M. Mercury. In: Friberg L, Nordberg GF, Vouk VB, ed. Handbook on the toxicology of metals; vol 2. Amsterdam: Elsevier, 1986:387-445.

2. Kosta L, Byrne AR, Zelenko V. Correlation between selenium and mercury in man following exposure to inorganic mercury. Nature 1975;254:238—9.

3. Léonard A, Jacquet P, Lauwerys RR. Mutagenicity and teratogenicity of mercury compounds. Mutat Res 1983;114:1-18.

4. Barregård L, Högstedt B, Schütz A, Karlsson A, Sällsten G, Thiringer G. Effects of occupational exposure to mercury vapor on lymphocyte micronuclei. Scand J Work Environ Health 1991;17:263-8.

5. Anwar WA, Gabal MS. Cytogenetic study in workers occupationally exposed to mercury fulminate. Mutagenesis $1991 ; 6: 189-92$.

6. Verschaeve L, Kirsch-Volders M, Susanne C, Groetenbriel C, Haustermans R, Lecomte A, et al. Genetic damage induced by occupationally low mercury exposure. Environ Res 1976;12:303-16.

7. Verschaeve L, Tassignon JP, Lefevre M, De Stoop P, Susanne C. Cytogenetic investigation on leukocytes of workers exposed to metallic mercury. Environ Mutagen 1979;1:259-68

8. Popescu HI, Negru L, Lancranjan I. Chromosome aberrations induced by occupational exposure to mercury. Arch Environ Health 1979;34:461 -3.

9. Mabille V, Roels H, Jacquet P, Léonard A, Lauwerys RR. Cytogenetic examination of leukocytes of workers exposed to mercury vapor. Int Arch Occup Environ Health 1984;53:257-60.

10. Ellingsen DG, Mørland T, Andersen A, Kjuus H. Relation between exposure related indices and neurological and neurophysiological effects in workers previously exposed to mercury vapor. $\mathrm{Br} \mathrm{J}$ Ind Med. In press.

11. Ellingsen DG, Holland RI, Thomassen Y, Landro-OIstad M, Frech W, Kjuus H. Mercury and selenium in workers previously exposed to mercury vapor at a chloralkali plant. Br J Ind Med. In press.

12. Jelmert $\emptyset$, Hansteen I-L, Langård S. Enhanced cytogenetic detection of previous in vivo exposure to mutagens in human lymphocytes after treatment with inhibitors of DNA-synthesis and DNA-repair in vitro. Mutat Res 1992;271:289-98.

13. Fenech M, Morley AA. Measurement of micronuclei in lymphocytes. Mutat Res 1985;147:29-36.

14. Hayashi M, Sofuni T, Ishidate M Jr. An application of acridine orange fluorescent staining to the micronucleus 747 test. Mutat Res 1983;120:241-7.

15. Palitti F, Tanzarella C, Degrassi F, De Salvia R, Fiore M. Enhancement of induced sister chromatid exchange 
and chromosomal aberrations by inhibitors of DNA repair processes. Toxicol Pathol 1984;12:269-73.

16. Kihlman BA, Andersson HC. Effects of inhibitors of DNA repair on the frequencies of chromosomal aberrations induced by X-rays or alkylating agents in cultured human lymphocytes. Prog Clin Biol Res 1986;209A:395-402.

17. Sakamoto-Hojo ET, Takahashi CS. Clastogenic action of ellipticine over the cell cycle of human lymphocytes and influence of posttreatments with caffeine and araC at $\mathrm{G}_{2}$. Mutat Res 1991;248:195-202.

18. Gundy S, Baki M, Bodrogi I, Czeizel A. Persistance of chromosomal aberrations in blood lymphocytes of testicular cancer patients. Oncology 1992;49:376-80.

19. Hongo T, Suzuki T, Himena S, Watanabe C, Satoh H, Shimada Y. Does mercury vapor exposure increase urinary selenium excretion? Ind Health 1985;23:

$$
163-5 .
$$

20. Barregård L, Thomassen Y, Schütz A, Marklund SL. Levels of selenium and antioxidative enzymes following occupational exposure to inorganic mercury. Sci Total Environ 1990;99:37-47.

21. Shamberger RJ. The genotoxicity of selenium. Mutat Res 1985;154:29-48.

22. Morimoto K, lijima S, Koizumi A. Selenite prevents the induction of sister-chromatid exchanges by methyl mercury and mercuric chloride in human whole-blood cultures. Mutat Res 1982;102:183-92.

23. Robison SH, Cantoni O, Costa M. Analysis of metalinduced DNA lesions and DNA-repair replication in mammalian cells. Mutat Res 1984;131:173—81.

Received for publication: 2 March 1993 